\title{
Evaluation of fecal fermentation profile and bacterial community in organically fed dairy cows consuming forage-rich diets with different particle sizes
}

\author{
Ezequias Castillo-Lopez, ${ }^{1 *} \odot$ Andreas Haselmann, ${ }^{2}$ (1) Renee M. Petri, ${ }^{1} \odot$ Wilhelm Knaus, ${ }^{2}$ () \\ and Qendrim Zebeli ${ }^{1}$ (i) \\ ${ }^{1}$ Institute of Animal Nutrition and Functional Plant Compounds, Department for Farm Animals and Veterinary Public Health, \\ University of Veterinary Medicine Vienna, 1210, Vienna, Austria \\ ${ }^{2}$ Division of Livestock Sciences, Department of Sustainable Agricultural Systems, BOKU-University of Natural Resources and Life Sciences, \\ 1180 Vienna, Austria
}

\section{ABSTRACT}

Organic cattle farming encourages the use of foragerich diets, and the reduction of particle size has been suggested as an approach to improve forage utilization and enhance nutrient intake of cows. However, reducing forage particle size increases passage rate, as well as the flow of potentially fermentable nutrients out of the rumen, and the consequences for hindgut fermentation have not been evaluated yet. This study evaluated the effects of decreasing dietary forage particle size on the fecal short-chain fatty acid (SCFA) profile and the bacterial community structure of dairy cows fed foragebased rations. Twenty-one organically fed lactating Holstein cows (4 primiparous and 17 multiparous; mean and standard deviation $703 \pm 65 \mathrm{~kg}$ body weight, 135 \pm 104 days in milk) were divided into 2 groups and fed 1 of 2 diets for 34 d. Diets contained $20 \%$ concentrate and $80 \%$ forage (dry matter basis), and were fed either as a control with a forage geometric mean particle size of $52 \mathrm{~mm}$ (CON; 11 cows) or as a diet with the forage particle size reduced to a geometric mean size of $7 \mathrm{~mm}$ (RED; 10 cows). Fecal samples were collected at the end of the experiment, and samples were immediately frozen at $-20^{\circ} \mathrm{C}$. Samples were analyzed for SCFA, and the fecal bacterial community was evaluated using $16 \mathrm{~S}$ rRNA sequencing. Data showed that the concentration of total SCFA was not affected by treatment, but the proportion of propionate, a key glucogenic precursor in cattle, tended to be greater for RED (13.3 and $13.8 \pm$ $0.1 \%$, respectively). The predominant bacterial phyla, including Firmicutes (58.0 $\pm 0.7 \%$ ), Bacteroidetes (26.9 $\pm 0.4 \%)$, and Verrucomicrobia $(4.0 \pm 0.4 \%)$, were not

Received December 10, 2019.

Accepted April 20, 2020.

*Corresponding author: ezequias.castillo-lopez@vetmeduni.ac.at affected by forage particle size. Family Lachnospiraceae increased in relative abundance when the RED diet was fed (12.1 and $13.9 \pm 0.5 \%$ for CON and RED, respectively), and genera Acetitomaculum (1.1 and 1.8 $\pm 0.2 \%)$, Turicibacter $(0.7$ and $0.9 \pm 0.1 \%)$, and $R u$ minobacter $(0.1$ and $0.4 \pm 0.1 \%)$ increased in relative abundance when RED was fed. In addition, relative abundance of some fecal bacterial taxa was correlated with major fecal SCFA and pH. Reducing the particle size of forages, from 52 to $7 \mathrm{~mm}$ geometric mean particle size, maintained fecal concentration of total SCFA and tended to enhance propionate concentration, without risk of dysbiosis. Thus, results suggest that reduction of forage particle size represents an effective approach to optimizing forage utilization while maintaining hindgut fermentation and fecal bacterial diversity in dairy cows fed forage-rich diets.

Key words: forage particle size, fecal fermentation profile, microbiota, DNA sequencing

\section{INTRODUCTION}

Conventional low-input dairy farming in general, and organic cattle farming specifically, encourage the use of forage-rich diets as a key tool to contribute to generation of food for human consumption (Wilkinson, 2011). Intercrop silages, such as grass-clover silage, are very common and effective in organic dairy farming from both soil and animal nutrition perspectives, allowing high biomass yields, favorable ensiling properties, and balanced nutritive value, compared with single-crop silage (Alstrup et al., 2016). Intercrop silage has been shown to be effective for maintaining rumen function (Naadland et al., 2017) and production performance (Dewhurst et al., 2003) of dairy cows. Coupled with grass hay, the diet becomes more palatable, and the long particle size contributes to physical effectiveness necessary for normal rumen function (Schulze et al., 
2015). However, diets rich in these forages limit the energy content in ruminant rations and decrease energy intake because of rumen fill (Allen, 1996, 2000). Therefore, one of the challenges when using high-forage rations is to meet the energy requirements of cows and to prevent decreases in nutrient supply and production performance, especially during early lactation (Kleefisch et al., 2018).

Reduction of forage particle size has been suggested as a mean to promote feed intake of cows by reducing the physical rumen fill, improving the homogeneity of the diet, and hence enhancing the overall appetite of cows (Tafaj et al., 2007; Nasrollahi et al., 2015). Our team has recently reported that reducing the particle size of grass-clover silage and grass hay resulted in increased DMI, total-tract nutrient digestibility, and overall estimated energy balance in lactating dairy cows (Haselmann et al., 2019). These results suggested that the improvement in nutrient digestion may have been due to the increment in feed total surface area, which may have facilitated microbial adhesion and enhanced microbial enzymatic activity, increasing fiber degradation (McAllister et al., 1994). This is particularly relevant for diets high in forages containing large amounts of slowly fermentable fibers, such as those used under organic production conditions. However, a disadvantage of reducing forage particle size, despite improving rumen nutrient degradation and lowering rumen physical fill, might be a decrease of mean retention time and an increase in the flow of potentially fermentable nutrients out of the rumen (Kammes and Allen, 2012; Dufreneix et al., 2019). This increased postruminal fermentation results in increased acidity of the latter segments of the gut, potentially affecting hindgut fermentation and the fecal microbiota. This condition has recently been recognized in cattle fed concentrate-rich diets (Tafaj et al., 2001; Zebeli et al., 2007; Khafipour et al., 2016), or when inducing subacute ruminal acidosis using ground alfalfa pellets (Plaizier et al., 2017), and might lead to hindgut dysbiosis and dysfermentation.

The hindgut plays an important role in cattle health and nutrient utilization and microbial fermentation of carbohydrates; this site is responsible for 5 to $10 \%$ of total-tract carbohydrate digestion in dairy cattle (Sutton, 1985; Gressley et al., 2011). Research evaluating the microbiota of the foregut (Fernando et al., 2010; Khafipour et al., 2016; Castillo-Lopez et al., 2017) and the hindgut of cattle (Petri et al., 2019) being fed high-grain diets has demonstrated that changes in diet chemical composition may lead to shifts in the bacterial community structure that may, in turn, influence nutrient metabolism and gut function. Nonetheless, less attention has been placed on the effects of changes in diet particle size on hindgut fermentation and the microbial community in cattle being fed forage-based rations. Therefore, the objective of the present experiment was to evaluate changes in the fecal short-chain fatty acid (SCFA) profile as well as in the fecal bacterial community structure of organically fed Holstein dairy cows fed forage-based rations with decreased forage particle size. We hypothesize that reduction in forage particle size may increase the availability of nutrients in the lower gut, resulting in a change in the fecal fermentation profile as a result of the lower $\mathrm{pH}$, and changes to the associated fecal bacterial community structure or diversity.

\section{MATERIALS AND METHODS}

The methods and protocols followed in this experiment were approved by the Institutional Ethics and Animal Welfare Committee of the University of Veterinary Medicine (Vetmeduni Vienna, Austria) and were in accordance with Austrian Good Scientific Practice guidelines and national legislation (protocol number ETK-07/10/2017). A companion paper reports details of the diets and their chemical compositions, methods of sample collection, and data for milk production performance, milk components, nutrient digestibility, and eating behavior (Haselmann et al., 2019).

\section{Experimental Design and Treatments}

In brief, 4 primiparous and 17 multiparous (2nd to 9th lactation) organically fed Holstein cows were used. Cows were assigned to 1 of the 2 treatment groups (1 control group and 1 experimental group) based on their average $( \pm \mathrm{SD})$ daily milk yield $(26.7 \pm 5.5 \mathrm{~kg})$, live weight at the beginning of the experiment $(703 \pm 65$ $\mathrm{kg})$, DIM $(135 \pm 104)$, and parity $(3.8 \pm 2.4)$. The study started with a baseline feeding period of $7 \mathrm{~d}$, followed by an experimental feeding period of $34 \mathrm{~d}$. During the baseline period, all cows received a TMR consisting of hay, clover-grass silage, corn silage, and a commercial concentrate premix including a mineral premix, to meet the requirements for energy and nutrients of cows with a BW of $700 \mathrm{~kg}$ and daily milk production of $30 \mathrm{~kg}$, according to GfE (2001). In our companion paper, only 16 of the 17 multiparous cows were used because one of them developed ketosis during the baseline period and was excluded from the analysis, given that data collected from the baseline period were used as covariates. During the treatment period, however, all cows remained healthy; therefore, all of them were included in this analysis for fecal fermentation profile and microbiota.

Rations included $43 \%$ grass hay, $37 \%$ clover-grass silage, and 20\% concentrate (DM basis). The latter 
included $40 \%$ field beans, $40 \%$ sunflower cake, $15 \%$ wheat bran, and $5 \%$ vitamin and mineral premix (DM basis). Specifically, treatments were control $(\mathbf{C O N})$, a diet with a conventional forage particle size (geometric mean of $52 \mathrm{~mm} ; 11$ cows), and reduced (RED) forage particle size (geometric mean of $7 \mathrm{~mm} ; 10$ cows). Treatments were designed so that the extent of geometric forage particle size reduction can increase DMI before reaching rumen fill; however, diets should also contain enough effective NDF to promote chewing activity (36.9 and $21.2 \%$ of effective $\mathrm{NDF}_{>8 \mathrm{~mm}}$ for $\mathrm{CON}$ and RED, respectively). Before preparing the RED TMR, both the hay and silage were chopped with a forage chopper (Blasisus 1034, Mengele Epple Maschinenbau, Wiesensteig, Germany) to a theoretical length of 0.5 $\mathrm{cm}$. The hay was then further shredded with a hammer mill equipped with 4 sets of hammers and a sieve with a mesh size of $20 \mathrm{~mm}$. Due to the low proportion of moisture in ingredients used in the rations, water was added to both TMR during mixing, to reach approximately $44 \%$ DM. The chemical composition and particle size distribution of the rations are reported in Haselmann et al. (2019). Briefly, treatments differed only in the particle size of forages. Crude protein, starch, NDF, and ether extract for both diets averaged 15.2, 0.35, 43.7, and 3.4\% (DM basis), respectively. Particle size distribution of TMR on an as-fed basis was measured by the method described by Kononoff et al. (2003), and based on these results, geometric mean length of particles $(\mathrm{Xgm})$ was calculated in accordance with ASAE (1992).

\section{Animal Care and Handling}

The experiment was conducted at the organic dairy farm of the Secondary School for Agriculture (Elixhausen, Austria). Cows were kept in a loose housing system with individual cubicles in accordance with the European regulations on organic farming (European Commission, 2008). Individual feeding was monitored by transponder-regulated Calan gates (American Calan Inc., Northwood, NH). Total mixed rations were mixed once a day and offered twice daily after milking (0600 and $1600 \mathrm{~h}$ ), with a target of $10 \%$ refusals.

\section{Fecal Sampling}

For the evaluation of fecal fermentation profile and the microbiota, samples were collected similarly to the procedure of Petri et al. (2019). Specifically, samples were taken rectally from each cow one time, between 0400 and $0430 \mathrm{~h}, 2 \mathrm{~d}$ before the end of the experiment, using a new palpation sleeve for each collection. After collection, fecal $\mathrm{pH}$ was measured using a portable $\mathrm{pH}$ meter (Mettler-Toledo AG Analytical, Schwerzenbach, Switzerland) by direct insertion of the $\mathrm{pH}$ sensor into the sample. Then, all samples were immediately frozen at $-20^{\circ} \mathrm{C}$ until later analysis. It is important to note that, although digesta samples were not collected through intestinal cannulas (Harmon and Richards, 1997; Castillo-Lopez et al., 2014), the use of rectally collected fecal samples to evaluate hindgut fermentation profile and microbial activity represents a reasonable approach (Gressley et al., 2011) without the implementation of invasive methods.

\section{SCFA Analyses}

At the end of the experiment, sample preparation for measurement of the concentration of SCFA in fecal samples was conducted as described by Petri et al. (2019) with minor modifications. Briefly, samples were thawed at room temperature and mixed thoroughly. Then, $1 \mathrm{~g}$ of fecal sample was diluted in $1 \mathrm{~mL}$ of water. Subsequently, $300 \mu \mathrm{L}$ of the internal standard 4-methylvaleric acid (Sigma-Aldrich, St. Louis, MO) and 200 $\mu \mathrm{L}$ of $25 \%$ phosphoric acid were added. Samples were mixed and centrifuged at $20,000 \times g$ for 20 min at $4^{\circ} \mathrm{C}$. After transferring the supernatant into a fresh tube, it was centrifuged until clear. The measurement of SCFA was conducted with a gas chromatography apparatus (GC Plus with FID detector, Shimadzu, Kyoto, Japan) equipped with a $30-\mathrm{m} \times 0.53-\mathrm{mm}$ internal diameter $\times 0.53-\mu \mathrm{m}$ film thickness capillary column (Trace TR Wax, Thermo Fisher Scientific, Waltham, MA). Injector and detector had temperatures of $170^{\circ} \mathrm{C}$ and $190^{\circ} \mathrm{C}$, respectively. Helium was used as carrier gas with a flow rate of $1 \mathrm{~mL} / \mathrm{min}$ (Qumar et al., 2016).

\section{DNA Extraction, Library Preparation, and Sequencing}

Isolation and purification of DNA was performed according to Bagheri Varzaneh et al. (2018) with minor modifications. Briefly, extraction was conducted from approximately $265 \mathrm{mg}$ of sample using the DNeasy PowerSoil Kit (Qiagen, Hilden, Germany). Samples were placed in bead beating tubes, and solution C1 was added and incubated at $95^{\circ} \mathrm{C}$ for 5 min. Then samples were centrifuged and supernatant was collected and placed on ice. The pellet was treated with $100 \mu \mathrm{L}$ of $100 \mathrm{mg} / \mathrm{mL}$ lysozyme and $10 \mu \mathrm{L}$ of $2.5 \mathrm{U} / \mathrm{mL}$ mutanolysin (Sigma-Aldrich) and incubated at $37^{\circ} \mathrm{C}$ for $30 \mathrm{~min}$. Then, $21 \mu \mathrm{L}$ of $18.6 \mathrm{mg} / \mathrm{mL}$ proteinase $\mathrm{K}$ (Sigma-Aldrich) was added and incubated at $37^{\circ} \mathrm{C}$ for $1 \mathrm{~h}$. Pellets were placed in a FastPrep-24 instrument 
(MP Biomedical, Santa Ana, CA) for bead beating. After centrifugation, the supernatant was collected. Removal of cell debris and PCR inhibitors was conducted via several centrifugation steps. The supernatant was transferred to new tubes, and DNA was eluted with $100 \mu \mathrm{L}$ of C6 buffer. Concentration was measured using a Qubit 2.0 Fluorometer (Life Technologies, Carlsbad, CA) with a Qubit double-stranded DNA HS Assay Kit (Life Technologies). Then, $40-\mu \mathrm{L}$ samples of DNA with an average concentration of $17.00 \mathrm{ng} / \mu \mathrm{L}$ were sent to an external laboratory (Microsynth, Balgach, Switzerland) for library preparation and sequencing.

The V3-V4 hypervariable region of the $16 \mathrm{~S}$ rRNA gene from the microbial communities was amplified using primers 341F/802R (Lladó et al., 2015; Probst et al., 2018) and sequenced with Illumina MiSeq pairedends sequencing technology (Microsynth). Multiplexed libraries were constructed by ligating sequencing adapters and indices onto purified PCR products using the Nextera XT Sample Preparation Kit (Illumina, Balgach, Switzerland). Primers were trimmed and corresponding overlapping paired-end reads were stitched by Microsynth.

\section{Bioinformatic Analysis of the Bacterial Community}

Filtration and operational taxonomic unit (OTU) identification of sequenced reads were performed according to Petri et al. (2019) using the bioinformatic pipeline QIIME (qiime.org; Caporaso et al., 2010). Reads were quality filtered using a phred quality score of Q20. Screening for chimeric sequences was performed using USEARCH 8.1 and the gold.fa database (Edgar et al., 2011). Sequences were then aligned and clustered to define OTU, using the last version of the SILVA128 database (https://www.arb-silva.de, version 128) as a reference template. Identity of each OTU was determined with $97 \%$ similarity of sequences to the database, and unique OTU were defined with a minimum of 10 sequences.

The resulting OTU table was then used for downstream analysis. $\alpha$-Diversity analysis using QIIME (Chao1, Shannon index, Simpson, observed OTU) was performed. Similar to Petri et al. (2019), principal coordinate analysis plots for $\beta$-diversity based on unweighted UniFrac analysis were generated with QIIME and visualized in 2-dimensional plots. Good's coverage test was performed to evaluate whether adequate sampling depth was achieved. The DNA sequence reads used in the analysis were deposited in the NCBI Sequence Read Archive at https://www.ncbi.nlm.nih.gov/sra (accession number PRJNA587106). A Venn diagram was constructed to illustrate the distribution relationship of OTU between treatments using the venn function in the gplots package of $\mathrm{R}$ (Warnes et al., 2015).

\section{Statistical Analysis}

Data collected on fecal fermentation were analyzed using the MIXED procedure of SAS (version 9.4; SAS Institute Inc., Cary, NC). Data were checked for normal distribution using the Shapiro-Wilk, KolmogorovSmirnov, Cramer-von Mises, and Anderson-Darling tests, and were checked to verify presence of outliers. Fixed effects included the treatment with cow nested within feeding group as the random effect. Cows were considered as the individual experimental unit. In addition, data collected for the abundance of the bacterial taxa at the levels of phylum, family, and genus, as well as $\alpha$-diversity (chao1, observed OTU, Shannon and Simpson), were compared with SAS. Treatment means were compared using the pdiff option in the lsmeans statement. Treatment means are presented as least squares means. The largest standard error of the mean is reported. In addition, the Pearson correlation coefficients between predominant bacterial taxa and major SCFA concentration and fecal $\mathrm{pH}$ were calculated using SAS. Statistical significance was declared when $P \leq$ 0.05 , and tendency was discussed if $P>0.05$ and $\leq$ 0.10 . Furthermore, bacterial community composition was evaluated using the Bray Curtis, weighted UniFrac, and unweighted UniFrac distance matrices as input for a permutational multivariate ANOVA (PERMANOVA) in $\mathrm{R}$ using the Adonis function of the vegan package (Oksanen et al., 2015), where treatment was used as main effect.

\section{RESULTS}

In our companion paper (Haselmann et al., 2019), we have shown that the reduction of forage particle size resulted in a significant decrease in the proportion of long particles $(>19 \mathrm{~mm})$ from $74 \pm 4$ to $23 \pm 4 \%$. At the same time, an increase occurred in the proportion of medium-sized particles $(8-19 \mathrm{~mm})$ from $10 \pm 2$ to 26 $\pm 1 \%$, and in the proportion of short particles (1.18-8 $\mathrm{mm}$ ) from $12 \pm 2$ to $37 \pm 3 \%$, as well as of small particles $(<1.18 \mathrm{~mm})$ from $5 \pm 1$ to $14 \pm 1 \%$. Furthermore, these results showed that reducing forage particle size increased DMI from 21.0 to $22.8 \mathrm{~kg}$, and increased total-tract digestibility of almost all nutrients, as well as increasing energy-corrected milk yield from 27.0 to $29.3 \mathrm{~kg}$, thus improving overall feed energy utilization. Furthermore, a tendency for a reduction in fecal $\mathrm{pH}(P$ $=0.06$ ) with the reduction of forage particle size was observed, with estimates of 7.25 and $7.17 \pm 0.03$. 
Table 1. Effect of reducing forage particle size on fecal short-chain fatty acid (SCFA) profile of organically fed lactating Holstein cows consuming a forage-rich TMR

\begin{tabular}{lrrrr}
\hline & \multicolumn{2}{c}{ Treatment $^{1}$} & & \\
\cline { 2 - 3 } Item & CON & RED & SEM $^{2}$ & $P$-value \\
\hline Total SCFA, $\mu \mathrm{mol} / \mathrm{g}$ & 57.3 & 55.7 & 4.2 & 0.79 \\
$\begin{array}{l}\text { \% of total SCFA } \\
\text { Acetate }\end{array}$ & 75.5 & 75.1 & 0.2 & 0.24 \\
Propionate & 13.3 & 13.8 & 0.1 & 0.08 \\
Butyrate & 4.9 & 4.9 & 0.1 & 0.88 \\
Isobutyrate & 4.0 & 3.7 & 0.2 & 0.34 \\
Isovalerate & 1.0 & 1.0 & 0.1 & 0.79 \\
Valerate & 1.1 & 1.2 & 0.1 & 0.43 \\
\hline
\end{tabular}

${ }^{1} \mathrm{CON}=\mathrm{TMR}$ containing (DM basis) $43 \%$ grass hay, $37 \%$ clover-grass silage, $8 \%$ field beans, $8 \%$ sunflower cake, $3 \%$ wheat bran, and $1 \%$ vitamin and mineral premix, with a geometric mean forage particle size of $52 \mathrm{~mm}$; RED = the same ingredients with the forage particle size reduced to a geometric mean size of $7 \mathrm{~mm}$.

${ }^{2}$ The largest SEM are reported.

\section{Fecal SCFA Profile}

The concentration of total SCFA in feces did not differ between treatments $(P=0.79)$. In addition, the proportion of acetate $(P=0.24)$, butyrate $(P=0.88)$, isobutyrate $(P=0.34)$, isovalerate $(P=0.79)$, and valerate $(P=0.43)$ remained unaffected. In contrast, the proportion of propionate tended $(P=0.08)$ to be greater in the feces of cows consuming the RED diet, with estimates of 13.3 and $13.8 \pm 0.1 \%$ for $\mathrm{CON}$ and RED, respectively (Table 1).

\section{Microbial Community Richness, Diversity, and Distribution}

A total of 815,441 DNA sequences were obtained from the 21 fecal samples, averaging 38,831 sequences per sample. Collectively, 750,901 high-quality DNA sequences were obtained after performing the quality-filtering and chimera-removal steps, and these sequences were used for downstream analyses. Sample richness estimates (Table 2) were not affected by treatment, as revealed by Chao1 $(P=0.25)$ and observed OTU $(P=$ $0.34)$. In addition, the Simpson $(P=0.98)$ and Shannon $(P=0.47)$ diversity indexes did not differ between CON and RED. Good's coverage values averaged 99.6 $\pm 0.1 \%$.

Bacterial community analysis for treatment effects using PERMANOVA did not display a significant effect of community composition using the unweighted UniFrac $(P=0.13)$, the weighted UniFrac $(P=0.27)$, or the Bray Curtis $(P=0.18)$ distance matrices. In addition, the principal coordinate analysis plots for sequence similarities (Figure 1) based on unweighted UniFrac analysis revealed no apparent clustering of microbial communities by treatment, indicating that spatial sample heterogeneity was similar between treatments. Venn diagram analysis (Figure 2) revealed that each diet showed only a few unique OTU, and that 1,210 OTU were shared by the 2 diets, representing 99.3\% of total OTU detected.

\section{Bacterial Community Composition}

The taxonomic analysis of the bacterial community revealed the presence of 15 phyla in the fecal microbiota (Table 3). No significant differences were detected in these communities at phylum level $(P \geq 0.11)$ between treatments. Specifically, the phylum Firmicutes was the most predominant, and its abundance $(P=0.28)$ averaged $58.03 \pm 0.75 \%$. The second most predominant phylum was Bacteroidetes, and its abundance $(P=$ 0.44 ) averaged $26.90 \pm 0.43 \%$ between treatments. The ratio of Firmicutes to Bacteroidetes (2.16 \pm 0.05$)$ also remained similar $(P=0.26)$ between treatments. Moreover, the abundance of the phyla Verrucomicrobia (4.04 $\pm 0.42 \%, P=0.82)$, Lentisphaera $(2.09 \pm 0.27 \%, P=$ $0.80)$, Actinobacteria $(1.88 \pm 0.17 \%, P=0.66)$, and Spirochaeta $(1.09 \pm 0.09 \%, P=0.23)$ were not affected. Other bacterial phyla found in lower proportions that remained unaffected by treatment were Saccharibacteria, Tenericutes, Proteobacteria, Fibrobacteres, Planctomycetes, Cyanobacteria, Chloroflexi, and Elusimicrobia. At this taxonomic level, only $1.70 \%$ of the bacterial community remained unclassified or unassigned.

We detected 80 bacterial families across samples. The most abundant are presented in Table 4, and most of them remained unaffected. For example, no treatment effect was observed on the abundance of the families Ruminococcaceae $(P=0.17)$, Rikenellaceae $(P=0.77)$, Prevotellaceae $(P=0.26)$, Peptostreptococcaceae $(P=$ $0.42)$, Bacteroidaceae $(P=0.61)$, and Christensenel-

Table 2. Effects of reducing forage particle size on bacterial richness estimates and diversity index in the feces of organically fed lactating Holstein cows consuming a forage-rich TMR

\begin{tabular}{|c|c|c|c|c|}
\hline \multirow[b]{2}{*}{ Item } & \multicolumn{2}{|c|}{ Treatment $^{1}$} & \multirow[b]{2}{*}{$\mathrm{SEM}^{2}$} & \multirow[b]{2}{*}{$P$-value } \\
\hline & $\mathrm{CON}$ & RED & & \\
\hline Chao1 & 1,126 & 1,099 & 16.2 & 0.25 \\
\hline Observed OTU ${ }^{3}$ & 1,057 & 1,033 & 18.3 & 0.34 \\
\hline Simpson & 0.992 & 0.992 & 0.001 & 0.98 \\
\hline Shannon & 8.334 & 8.293 & 0.039 & 0.47 \\
\hline
\end{tabular}

${ }^{1} \mathrm{CON}=\mathrm{TMR}$ containing (DM basis) $43 \%$ grass hay, $37 \%$ clover-grass silage, $8 \%$ field beans, $8 \%$ sunflower cake, $3 \%$ wheat bran, and $1 \%$ vitamin and mineral premix, with a geometric mean forage particle size of $52 \mathrm{~mm} ; \mathrm{RED}=$ the same ingredients with the forage particle size reduced to a geometric mean size of $7 \mathrm{~mm}$.

${ }^{2}$ The largest SEM are reported.

${ }^{3} \mathrm{OTU}=$ operational taxonomic units. 
laceae $(P=0.99)$. However, treatment effects were observed in the abundance of a few major bacterial families. Specifically, the abundance of Lachnospiraceae increased $(P=0.05)$, with estimates of 12.17 and 13.95 $\pm 0.59 \%$ for CON and RED, respectively. Similarly, the abundance of the family Erysipelotrichaceae $(P=0.05)$ increased, but an unclassified family identified as BS11 gut group $(P=0.03)$ decreased with RED treatment. Only minor numerical variations were observed in the abundance of the rest of the bacterial families.

Taxonomic classification of the microbiota at the genus level revealed the presence of 206 bacterial genera.
Table 5 lists the most abundant. No effect of diet was observed on the abundance of an unclassified Ruminococcaceae genus identified as UCG-005 $(P=0.40)$ and another identified as UCG-010 $(P=0.58)$, a genus belonging to Rikenellaceae known as RC9 gut group ( $P$ $=0.41$ ), a genus belonging to Lachnospiraceae identified as NK3A20 $(P=0.77)$, Bacteroides $(P=0.61)$, and Alistipes $(P=0.69)$. However, treatment effects were observed in the abundance of some genera. For example, compared with $\mathrm{CON}$, the abundance of the genera Acetitomaculum $(P<0.05)$, Turicibacter $(P<$ $0.05)$, Ruminobacter $(P=0.05)$, and the genus $A n$ -

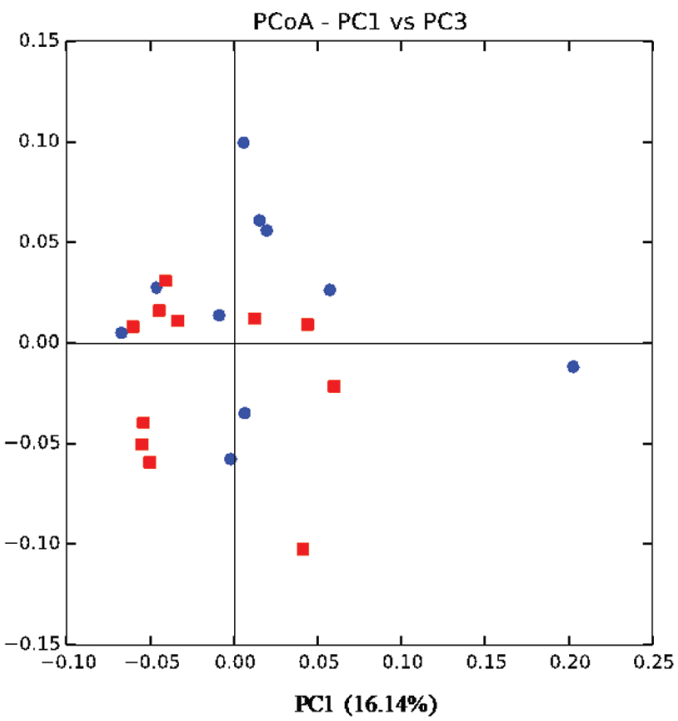

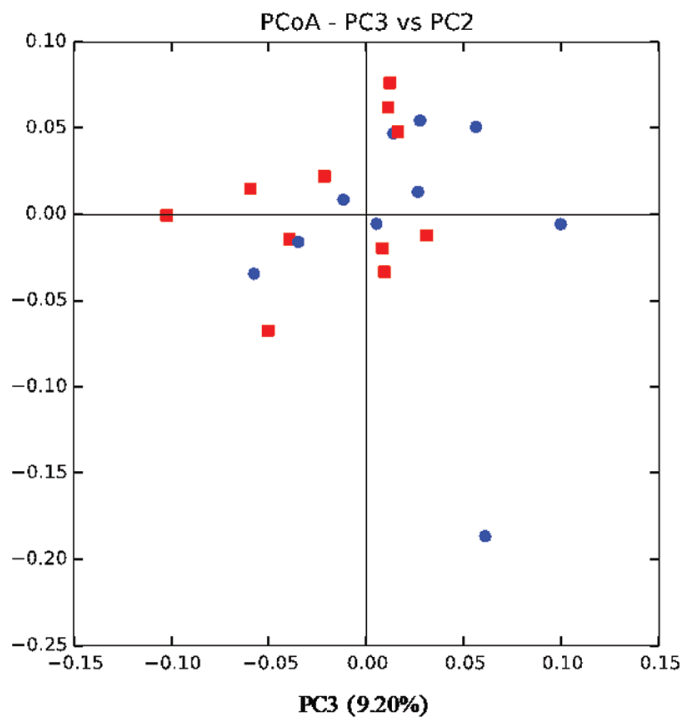

Figure 1. $\beta$-Diversity of treatment groups based on unweighted UniFrac analysis in a 2-dimensional principal coordinate analysis (PCoA) plot. Principal components ( $\mathrm{PC} 1=16.14 \%$; $\mathrm{PC} 2=13.43 \%$; PC3 $=9.20 \%$ ) explain $39 \%$ of the total variation between samples. Red squares $=$ control (CON) treatment, containing (DM basis) $43 \%$ grass hay, 37\% clover-grass silage, $8 \%$ field beans, $8 \%$ sunflower cake, $3 \%$ wheat bran, and $1 \%$ vitamin and mineral premix, with a geometric mean forage particle size of $52 \mathrm{~mm}$; blue circles = experimental treatment (RED), containing the same ingredients with forage particle size reduced to a geometric mean size of $7 \mathrm{~mm}$. 


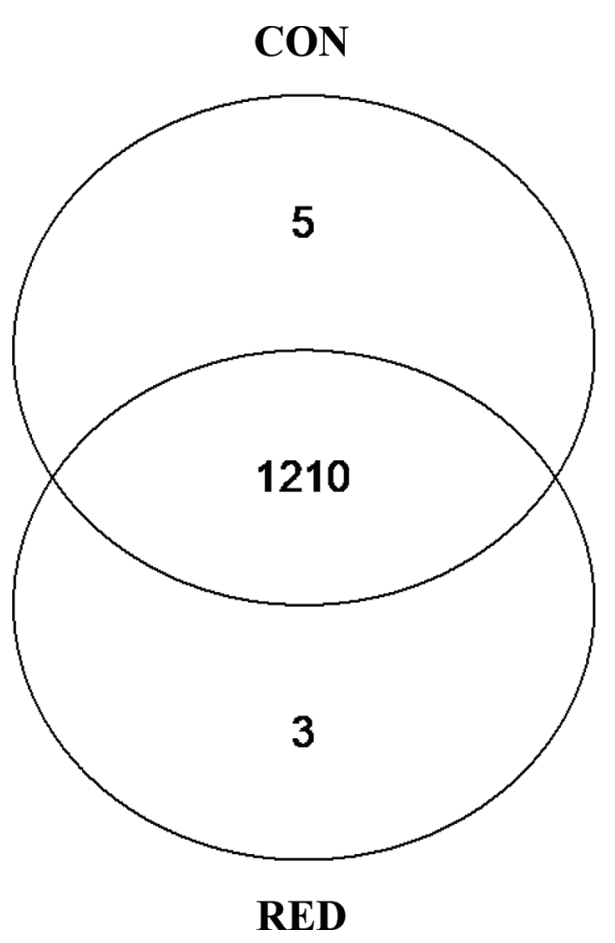

Figure 2. Venn diagram of operational taxonomic unit (OTU) relationship between treatments. Each circle represents the type of diet. Numbers in overlapping area indicate the number of OTU in common between the corresponding treatments; numbers in non-overlapping areas of circles indicate OTU not shared between the treatments. CON $=$ TMR containing (DM basis) $43 \%$ grass hay, 37\% clover-grass silage, $8 \%$ field beans, $8 \%$ sunflower cake, $3 \%$ wheat bran, and $1 \%$ vitamin and mineral premix, with a geometric mean forage particle size of 52 $\mathrm{mm} ; \mathrm{RED}=$ the same ingredients with forage particle size reduced to a geometric mean size of $7 \mathrm{~mm}$.

aerosporobacter increased $(P<0.05)$ when RED was fed. Furthermore, a tendency for greater abundance of Coprococcus $(P=0.10)$ occurred when RED diet was fed to cows compared with CON. Similar to our observations at the taxonomical level of family, only minor variations were observed on the abundance of the rest of the bacterial genera found in lower proportions.

\section{Correlation Coefficients Between the Fecal Bacterial Community, SCFA, and $\mathrm{pH}$}

The proportions of individual SCFA were correlated with several bacterial taxa (Table 6). For example, acetate was positively correlated $(P<0.05)$ with a genus belonging to the family Ruminococcaceae identified as UCG-005, and with a group belonging to family XIII identified as AD3011. However, it tended to be negatively correlated $(P=0.06)$ with the genus Acetitomaculum. Propionate was positively correlated $(P<$ 0.05) with a Bacteroidales group identified as RF16, Victivallaceae, a Bacteroidales group identified as S247 , and with a group of uncultured bacteria. However,
Table 3. Effects of reducing forage particle size on the abundance (\%) of major fecal bacterial phyla of organically fed lactating Holstein cows consuming a forage-rich TMR

\begin{tabular}{|c|c|c|c|c|}
\hline \multirow[b]{2}{*}{ Phylum ${ }^{1}$} & \multicolumn{2}{|c|}{ Treatment $^{2}$} & \multirow[b]{2}{*}{$\mathrm{SEM}^{3}$} & \multirow[b]{2}{*}{$P$-value } \\
\hline & $\mathrm{CON}$ & RED & & \\
\hline Firmicutes & 57.40 & 58.67 & 0.75 & 0.28 \\
\hline Bacteroidetes & 27.14 & 26.65 & 0.43 & 0.44 \\
\hline Verrucomicrobia & 4.11 & 3.98 & 0.42 & 0.82 \\
\hline Lentisphaerae & 2.14 & 2.05 & 0.27 & 0.80 \\
\hline Actinobacteria & 1.94 & 1.83 & 0.17 & 0.66 \\
\hline Spirochaetae & 1.17 & 1.02 & 0.09 & 0.23 \\
\hline Euryarchaeota & 1.12 & 0.91 & 0.15 & 0.35 \\
\hline Saccharibacteria & 0.88 & 0.76 & 0.09 & 0.39 \\
\hline Tenericutes & 0.69 & 0.74 & 0.05 & 0.46 \\
\hline Proteobacteria & 0.56 & 0.88 & 0.10 & 0.06 \\
\hline Fibrobacteres & 0.37 & 0.30 & 0.04 & 0.31 \\
\hline Planctomycetes & 0.38 & 0.26 & 0.02 & 0.11 \\
\hline Cyanobacteria & 0.26 & 0.20 & 0.05 & 0.41 \\
\hline Chloroflexi & 0.01 & 0.00 & 0.01 & 0.24 \\
\hline Elusimicrobia & 0.01 & 0.00 & 0.01 & 0.20 \\
\hline Unassigned & 1.30 & 1.13 & 0.15 & 0.39 \\
\hline Other & 0.43 & 0.54 & 0.04 & 0.13 \\
\hline Firmicutes/Bacteroidetes & 2.11 & 2.21 & 0.05 & 0.26 \\
\hline
\end{tabular}

${ }^{1}$ Classification of operational taxonomic units based on the SILVA database (https://www.arb-silva.de, version 128), with $97 \%$ similarity. ${ }^{2} \mathrm{CON}=\mathrm{TMR}$ containing (DM basis) $43 \%$ grass hay, $37 \%$ clover-grass silage, $8 \%$ field beans, $8 \%$ sunflower cake, $3 \%$ wheat bran, and $1 \%$ vitamin and mineral premix, with a geometric mean forage particle size of $52 \mathrm{~mm}$; RED = the same ingredients with forage particle size reduced to a geometric mean size of $7 \mathrm{~mm}$.

${ }^{3}$ The largest SEM are reported.

it was negatively correlated with Bacteroidaceae $(P$ $<0.05)$, with Peptostreptococcaceae $(P=0.06)$, and with 2 groups of the family Ruminococcaceae identified as UCG-005 $(P=0.08)$ and NK4A214 $(P<0.05)$. In addition, butyrate was positively correlated $(P<$ 0.05) with a Bacteroidales group identified as RF16, Victivallaceae $(P<0.01)$, Spirochaetaceae $(P=0.06)$, an uncultured bacterial group $(P<0.01)$, and a group belonging to Ruminococcaceae known as UCG-010 ( $P=$ $0.05)$. However, it was negatively correlated $(P<0.05)$ with the family XIII, Dorea, and a Prevotellaceae group identified as UCG-003. Branched SCFA also displayed correlations with several taxa, including positive correlation $(P<0.05)$ between isobutyrate and Bacteroidaceae and Coriobacteriaceae, but negative correlation with Christensenellaceae $(P=0.09)$ and Victivallaceae $(P<0.05)$. Isovalerate was positively correlated $(P<$ $0.05)$ with Phocaeicola and negatively correlated $(P<$ $0.05)$ with abundance of Prevotella. Fecal $\mathrm{pH}$ was negatively correlated $(P<0.05)$ with Succinivibrionaceae and with Ruminobacter.

\section{DISCUSSION}

The present study was conducted to evaluate changes in fecal fermentation profile as well as the fe- 
Table 4. Effects of reducing forage particle size on the abundance (\%) of major fecal bacterial families of organically fed lactating Holstein cows consuming a forage-rich TMR

\begin{tabular}{|c|c|c|c|c|c|}
\hline \multirow[b]{2}{*}{ Order } & \multirow[b]{2}{*}{ Family $^{1}$} & \multicolumn{2}{|c|}{ Treatment $^{2}$} & \multirow[b]{2}{*}{$\mathrm{SEM}^{3}$} & \multirow[b]{2}{*}{$P$-value } \\
\hline & & $\mathrm{CON}$ & RED & & \\
\hline \multirow[t]{8}{*}{ Clostridiales } & Ruminococcaceae & 32.18 & 31.04 & 0.55 & 0.17 \\
\hline & Lachnospiraceae & 12.17 & 13.95 & 0.59 & 0.05 \\
\hline & Peptostreptococcaceae & 3.81 & 4.17 & 0.31 & 0.42 \\
\hline & Christensenellaceae & 2.48 & 2.47 & 0.10 & 0.99 \\
\hline & XIII & 1.63 & 1.56 & 0.06 & 0.36 \\
\hline & vadinBB60 group & 1.35 & 1.29 & 0.08 & 0.62 \\
\hline & Clostridiaceae & 0.44 & 0.50 & 0.05 & 0.37 \\
\hline & Peptococcaceae & 0.24 & 0.22 & 0.02 & 0.41 \\
\hline \multirow[t]{9}{*}{ Bacteroidales } & Rikenellaceae & 8.76 & 8.66 & 0.26 & 0.77 \\
\hline & Prevotellaceae & 6.78 & 6.32 & 0.28 & 0.26 \\
\hline & Bacteroidaceae & 3.67 & 3.74 & 0.11 & 0.61 \\
\hline & $R F 16$ group & 1.93 & 1.97 & 0.15 & 0.82 \\
\hline & Incertae sedis & 1.24 & 1.26 & 0.06 & 0.84 \\
\hline & S24-7 group & 1.12 & 1.31 & 0.15 & 0.41 \\
\hline & Porphyromonadaceae & 1.04 & 1.09 & 0.04 & 0.37 \\
\hline & p-2534-18B5 gut group & 1.17 & 0.94 & 0.09 & 0.11 \\
\hline & BS11 gut group & 0.48 & 0.30 & 0.05 & 0.03 \\
\hline Erysipelotrichales & Erysipelotrichaceae & 1.68 & 2.05 & 0.12 & 0.05 \\
\hline Coriobacteriales & Coriobacteriaceae & 1.83 & 1.70 & 0.16 & 0.58 \\
\hline \multirow[t]{2}{*}{ Victivallales } & Victivallaceae & 1.75 & 1.66 & 0.21 & 0.78 \\
\hline & vadinBE97 & 0.28 & 0.29 & 0.05 & 0.91 \\
\hline Spirochaetales & Spirochaetaceae & 1.18 & 1.00 & 0.09 & 0.20 \\
\hline Verrucomicrobiales & Verrucomicrobiaceae & 0.82 & 0.71 & 0.09 & 0.40 \\
\hline Selenomonadales & Acidaminococcaceae & 0.59 & 0.58 & 0.02 & 0.65 \\
\hline Fibrobacterales & Fibrobacteraceae & 0.37 & 0.30 & 0.04 & 0.30 \\
\hline Planctomycetales & Planctomycetaceae & 0.38 & 0.26 & 0.04 & 0.10 \\
\hline Anaeromonadales & Succinivibrionaceae & 0.11 & 0.40 & 0.09 & 0.05 \\
\hline Rhodospirillales & Rhodospirillaceae & 0.19 & 0.14 & 0.03 & 0.37 \\
\hline Unkown & Other & 9.24 & 9.22 & 0.20 & 0.53 \\
\hline \multicolumn{6}{|c|}{$\begin{array}{l}{ }^{1} \text { Classification of operational taxonomic units based on the SILVA database (https://www.arb-silva.de, versic } \\
128 \text { ), with } 97 \% \text { similarity. }\end{array}$} \\
\hline \multicolumn{6}{|c|}{$\begin{array}{l}{ }^{2} \mathrm{CON}=\mathrm{TMR} \text { containing (DM basis) } 43 \% \text { grass hay, } 37 \% \text { clover-grass silage, } 8 \% \text { field beans, } 8 \% \text { sunflowe } \\
\text { cake, } 3 \% \text { wheat bran, and } 1 \% \text { vitamin and mineral premix, with a geometric mean forage particle size of } 5 \\
\mathrm{~mm} \text {; RED = the same ingredients with forage particle size reduced to a geometric mean size of } 7 \mathrm{~mm} \text {. } \\
{ }^{3} \text { The largest SEM are reported. }\end{array}$} \\
\hline
\end{tabular}

cal bacterial community structure of organically fed Holstein dairy cows consuming forage-based rations with decreased forage particle size. The rationale behind the forage particle size reduction was to increase DMI before reaching rumen fill. However, rations should also have enough effective NDF so that chewing activity is stimulated. In our companion paper, results showed that feeding the RED diet increased DMI by $1.8 \pm 0.2 \mathrm{~kg} / \mathrm{d}$ and tended to decrease fecal $\mathrm{pH}$ by 0.08 units. Therefore, we hypothesized that a reduction in forage particle size may increase the flow of potentially fermentable nutrients to the lower gut, resulting in a change in the fecal fermentation profile and, with the lower alkalinity, in the associated fecal bacterial community structure. Characterization of the fecal fermentation and ecology is important because hindgut fermentation not only contributes to overall energy and nutrient supply to the host, but hindgut dysbiosis impairs cattle health (Gressley et al., 2011; Mao et al., 2012; Khafipour et al., 2016). Although physiologically small, the difference in fecal $\mathrm{pH}$ indicates an increase in the flow of fermentable nutrients in the hindgut with feeding the RED diet (Gressley et al., 2011). Consequently, the increased fecal fermentation may have favored the growth of the bacterial taxa that proliferate with easily fermentable nutrients. However, our results also indicate that bacterial diversity, as well as the most predominant bacterial taxa, remained unaffected. Differences in fecal $\mathrm{pH}$ are expected to be smaller than differences in $\mathrm{pH}$ in the rumen due to lower fermentation intensity in the hindgut compared with the rumen (Dijkstra et al., 2012). In addition, the neutralization and buffering system in the hindgut (Sutton, 1985), primarily due to pancreatic secretions (Zabielski et al., 1997), contributes to regulation of hindgut digesta $\mathrm{pH}$. Given that we did not measure fermentation in the rumen, we are unsure to what extent ruminal fermentation parameters changed in cows consuming forages with reduced particle size compared with the control group. 
Table 5. Effects of reducing forage particle size on the abundance (\%) of major fecal bacterial genera of organically fed lactating Holstein cows consuming a forage-rich TMR

\begin{tabular}{|c|c|c|c|c|c|}
\hline \multirow[b]{2}{*}{ Family } & \multirow[b]{2}{*}{ Genus $^{1}$} & \multicolumn{2}{|c|}{ Treatment $^{2}$} & \multirow[b]{2}{*}{$\mathrm{SEM}^{3}$} & \multirow[b]{2}{*}{$P$-value } \\
\hline & & $\mathrm{CON}$ & RED & & \\
\hline \multirow[t]{11}{*}{ Ruminococcaceae } & UCG-005 & 10.79 & 10.40 & 0.33 & 0.40 \\
\hline & UCG-010 & 8.26 & 7.96 & 0.39 & 0.58 \\
\hline & Eubacterium & 2.75 & 2.91 & 0.11 & 0.30 \\
\hline & UCG-013 & 1.94 & 1.83 & 0.09 & 0.41 \\
\hline & UCG-014 & 1.30 & 1.04 & 0.13 & 0.17 \\
\hline & UCG-009 & 0.78 & 0.79 & 0.03 & 0.88 \\
\hline & NK4A214 group & 0.77 & 0.79 & 0.04 & 0.67 \\
\hline & Anaerotruncus & 0.41 & 0.42 & 0.02 & 0.63 \\
\hline & UCG-011 & 0.39 & 0.36 & 0.02 & 0.32 \\
\hline & Ruminococcus & 0.71 & 0.76 & 0.11 & 0.77 \\
\hline & Ruminococcus gauvreauii group & 0.26 & 0.32 & 0.03 & 0.27 \\
\hline \multirow[t]{3}{*}{ Rikenellaceae } & RC9 gut group & 4.70 & 4.53 & 0.14 & 0.41 \\
\hline & Alistipes & 3.41 & 3.50 & 0.17 & 0.69 \\
\hline & $\mathrm{dg} \mathrm{A}-11$ gut group & 0.63 & 0.62 & 0.04 & 0.72 \\
\hline \multirow[t]{9}{*}{ Lachnospiraceae } & NK3A20 group & 3.92 & 3.83 & 0.22 & 0.77 \\
\hline & Acetitomaculum & 1.14 & 1.86 & 0.19 & 0.02 \\
\hline & NK4A136 group & 0.43 & 0.50 & 0.02 & 0.11 \\
\hline & Roseburia & 0.41 & 0.46 & 0.04 & 0.45 \\
\hline & Tyzzerella & 0.36 & 0.35 & 0.04 & 0.89 \\
\hline & Dorea & 0.29 & 0.30 & 0.02 & 0.75 \\
\hline & Coprococcus & 0.23 & 0.29 & 0.02 & 0.10 \\
\hline & Anaerosporobacter & 0.21 & 0.30 & 0.03 & 0.01 \\
\hline & Marvinbryantia & 0.23 & 0.27 & 0.02 & 0.22 \\
\hline Bacteroidaceae & Bacteroides & 3.67 & 3.74 & 0.11 & 0.61 \\
\hline \multirow[t]{5}{*}{ Prevotellaceae } & UCG-003 & 2.68 & 2.55 & 0.19 & 0.63 \\
\hline & UCG-004 & 1.66 & 1.46 & 0.10 & 0.14 \\
\hline & Alloprevotella & 1.52 & 1.32 & 0.11 & 0.13 \\
\hline & Prevotella & 0.43 & 0.42 & 0.05 & 0.94 \\
\hline & UCG-001 & 0.38 & 0.40 & 0.03 & 0.68 \\
\hline Peptostreptococcaceae & Peptoclostridium & 2.38 & 2.59 & 0.17 & 0.39 \\
\hline Christensenellaceae & $R-7$ group & 2.44 & 2.44 & 0.10 & 0.98 \\
\hline Insertae sedis & Phocaeicola & 1.24 & 1.26 & 0.06 & 0.84 \\
\hline Coriobacteriaceae & Olsenella & 1.24 & 1.07 & 0.13 & 0.36 \\
\hline Spirochaetaceae & Treponema & 1.17 & 1.00 & 0.09 & 0.21 \\
\hline Erysipelotrichaceae & Turicibacter & 0.74 & 0.96 & 0.07 & 0.04 \\
\hline Unidentified family & Candidatus Saccharimonas & 0.88 & 0.76 & 0.09 & 0.39 \\
\hline Verrucomicrobiaceae & Akkermansia & 0.82 & 0.71 & 0.09 & 0.40 \\
\hline \multirow[t]{2}{*}{ Family XIII } & AD3011 group & 0.85 & 0.78 & 0.04 & 0.12 \\
\hline & Eubacterium brachy group & 0.34 & 0.35 & 0.02 & 0.98 \\
\hline Acidaminococcaceae & Phascolarctobacterium & 0.59 & 0.58 & 0.02 & 0.65 \\
\hline Clostridiaceae & Clostridium sensu stricto & 0.44 & 0.40 & 0.05 & 0.37 \\
\hline \multirow[t]{2}{*}{ Eubacteriaceae } & Eubacterium hallii group & 0.43 & 0.45 & 0.02 & 0.54 \\
\hline & Eubacterium nodatum group & 0.25 & 0.26 & 0.01 & 0.91 \\
\hline Fibrobacteraceae & Fibrobacter & 0.37 & 0.30 & 0.04 & 0.30 \\
\hline Planctomycetaceae & p-1088-a5 gut group & 0.37 & 0.26 & 0.04 & 0.10 \\
\hline Succinivibrinaceae & Ruminobacter & 0.11 & 0.40 & 0.09 & 0.05 \\
\hline Unknown & Uncultured & 13.13 & 13.14 & 0.57 & 0.98 \\
\hline Unknown & Other & 8.58 & 8.93 & 0.38 & 0.53 \\
\hline
\end{tabular}

${ }^{1}$ Classification of operational taxonomic units based on the SILVA database (https://www.arb-silva.de, version 128), with $97 \%$ similarity.

${ }^{2} \mathrm{CON}=$ TMR containing (DM basis) $43 \%$ grass hay, $37 \%$ clover-grass silage, $8 \%$ field beans, $8 \%$ sunflower cake, $3 \%$ wheat bran, and $1 \%$ vitamin and mineral premix, with a geometric mean forage particle size of 52 $\mathrm{mm} ; \mathrm{RED}=$ the same ingredients with forage particle size reduced to a geometric mean size of $7 \mathrm{~mm}$.

${ }^{3}$ The largest SEM are reported.

The tendency for a higher fecal propionate concentration may have contributed, but only slightly, to the overall supply of propionate in cows fed the RED diet, assuming that propionate production in the rumen was not reduced. This is highly important because dairy cows have large demands for glucose, and propionate is the main precursor of glucose during gluconeogenesis. When cows consumed the RED diet, milk protein and lactose remained unaffected, but cows produced more energy-corrected milk, and body weight increment was greater by $0.47 \mathrm{~kg} / \mathrm{d}$ (Haselmann et al., 2019). The increase in feed surface area and the tendency for extend- 
Table 6. Correlation coefficients (r) between the abundance of bacterial families and genera in feces and major fecal short-chain fatty acids and $\mathrm{pH}$ for lactating Holstein cows fed a forage-rich TMR ${ }^{1}$

\begin{tabular}{|c|c|c|c|}
\hline Item & Bacterial family or genus & $\mathrm{r}$ & $P$-value \\
\hline \multirow[t]{5}{*}{ Acetate, $\%$} & Family XIII & 0.376 & 0.092 \\
\hline & Ruminococcaceae UCG-005 & 0.490 & 0.023 \\
\hline & Acetitomaculum & -0.415 & 0.060 \\
\hline & Family XIIIAD3011 group & 0.450 & 0.040 \\
\hline & Roseburia & 0.397 & 0.074 \\
\hline \multirow[t]{11}{*}{ Propionate, \% } & Bacteroidaceae & -0.605 & 0.003 \\
\hline & Peptostreptococcaceae & -0.414 & 0.061 \\
\hline & Bacteroidales RF16 group & 0.546 & 0.010 \\
\hline & Victivallaceae & 0.438 & 0.047 \\
\hline & Bacteroidales S24-7 group & 0.610 & 0.003 \\
\hline & Uncultured bacteria & 0.525 & 0.014 \\
\hline & Ruminococcaceae UCG-005 & -0.381 & 0.087 \\
\hline & Bacteroides & -0.605 & 0.003 \\
\hline & Olsenella & -0.540 & 0.011 \\
\hline & Ruminococcaceae NK4A214 group & -0.466 & 0.033 \\
\hline & Coriobacteriaceae & -0.518 & 0.016 \\
\hline \multirow[t]{11}{*}{ Butyrate, \% } & Bacteroidales RF16 group & 0.524 & 0.014 \\
\hline & Coriobacteriaceae & -0.552 & 0.009 \\
\hline & Victivallaceae & 0.566 & 0.007 \\
\hline & Family XIII & -0.710 & 0.001 \\
\hline & Bacteroidales BS11 gut group & 0.423 & 0.055 \\
\hline & Uncultured bacterium & 0.620 & 0.001 \\
\hline & Spirochaetaceae & 0.412 & 0.063 \\
\hline & Ruminococcaceae UCG-010 & 0.427 & 0.053 \\
\hline & Olsenella & -0.531 & 0.013 \\
\hline & Dorea & -0.507 & 0.019 \\
\hline & Prevotellaceae UCG-003 & -0.486 & 0.025 \\
\hline \multirow[t]{4}{*}{ Valerate, $\%$} & Alistipes & 0.438 & 0.046 \\
\hline & Ruminococcaceae NK4A214 group & 0.430 & 0.051 \\
\hline & Prevotella & -0.444 & 0.043 \\
\hline & Ruminococcus & -0.430 & 0.051 \\
\hline \multirow[t]{9}{*}{ Isobutyrate, $\%$} & Bacteroidaceae & 0.535 & 0.012 \\
\hline & Christensenellaceae & -0.374 & 0.094 \\
\hline & Coriobacteriaceae & 0.741 & 0.016 \\
\hline & Victivallaceae & -0.678 & 0.047 \\
\hline & Family XIII & 0.582 & 0.055 \\
\hline & Uncultured bacterium & -0.734 & 0.001 \\
\hline & Bacteroidales RF16 group & -0.580 & 0.005 \\
\hline & Lachnospiraceae NK3A20 group & 0.576 & 0.006 \\
\hline & Ruminococcus gauvreauii group & 0.445 & 0.043 \\
\hline \multirow[t]{3}{*}{ Isovalerate, $\%$} & Bacteroidales BS11 gut group & 0.461 & 0.035 \\
\hline & Phocaeicola & 0.435 & 0.048 \\
\hline & Prevotella & -0.502 & 0.020 \\
\hline \multirow{2}{*}{ Fecal pH } & Succinivibrionaceae & -0.667 & 0.001 \\
\hline & Ruminobacter & -0.667 & 0.001 \\
\hline
\end{tabular}

${ }^{1}$ Control (CON) TMR contained (DM basis) $43 \%$ grass hay, 37\% clover-grass silage, $8 \%$ field beans, $8 \%$ sunflower cake, $3 \%$ wheat bran, and $1 \%$ vitamin and mineral premix, with a geometric mean forage particle size of $52 \mathrm{~mm}$; experimental (RED) TMR contained the same ingredients with forage particle size reduced to a geometric mean size of $7 \mathrm{~mm}$.

ed ruminating time (Haselmann et al., 2019) may have increased the availability of nonfiber carbohydrates, promoting the activity and proliferation of propionateproducing bacteria such as Lachnospiraceae and Ruminobacter (Schären et al., 2017; San-Juan-Vergara et al., 2018) when the RED diet was fed. Our findings also agree with reports showing that Succinivibrionacceae and Ruminobacter proliferate under reduced $\mathrm{pH}$ conditions (Zhao et al., 2018) and may contribute to propionate production, as reported by other researchers evaluating ruminal fermentation (Wallace et al., 2015).
In this study, the lack of effect on fecal acetate may be due to the absence of a change in the abundance of the fiber-digesting taxa Ruminococcaceae and Fibrobacteracea, because fiber digestion generates acetate. It is important to note that we measured concentration of SCFA but not total amount produced, and we are unsure whether total production of SCFA changed with the reduction of forage particle size.

Changing the particle size of forages may influence not only nutrient supply for the host and production performance (Nasrollahi et al., 2015; Tayyab et al., 
2018) but also substrates and metabolic pathways of microbes (Russell and Wilson, 1996; Mertens, 1997) and, thus, the microbial habitat. The influence of diet on the microbiota of the foregut (de Menezes et al., 2011; Castillo-Lopez et al., 2014; Khafipour et al., 2016) and hindgut (Dowd et al., 2008; Callaway et al., 2010; Khafipour et al., 2016) of cattle has been recognized. For example, a change in nutrient supply and availability can shift the community structure (Plaizier et al., 2017, 2018) or bacterial diversity (Tao et al., 2017). Therefore, understanding the effects of the magnitude and the type of ingredients being changed in particle size is important for improving roughage utilization in forage-based dairy rations while preventing detrimental effects on nutrient metabolism and the gut microbiota (Dunkley et al., 2007; Callaway et al., 2008). Similar to the results of Durso et al. (2010) and Shanks et al. (2011), the predominant phyla in the feces in this study were Bacteroidetes and Firmicutes, representing close to $80 \%$ of total population. In this study, no evidence of dysbiosis was found, and fecal bacterial diversity was maintained with the reduction of forage particle size.

Similar to Mao et al. (2012) and Shanks et al. (2011), we found that Prevotellaceae, Ruminococcaceae, and Bacteroidaceae are among most abundant families in the fecal microbiota of cows. Ruminococcaceae and Prevotellaceae represented around $40 \%$ of total bacteria. In addition, the genus Coprococcus has also been reported to proliferate in the feces of animals fed high-fiber diets (Velasco-Galilea et al., 2018), suggesting an important role in fermentation at the end of the digestion process in cattle fed forage-rich rations. Although a significant statistical correlation does not necessarily indicate a direct cause-effect relationship, it is possible that the significant correlations observed between some bacterial taxa and the concentrations of individual SCFA reflect nutrient preference and their participation in the generation of specific SCFA. For example, Ruminococcaceae includes members that digest fiber-promoting acetate production (Van Soest, 1994). Our results also agree with Ribeiro et al. (2017), indicating that bacteria belonging to BS11 can degrade hemicellulose and produce butyrate, which explains the positive correlations with those specific SCFA. Moreover, the negative correlation found between the taxa Prevotella and valerate and isovalerate may indicate that an increment in their abundance or metabolic capacity supported the production of other SCFA such as acetate and propionate (Russell, 2002), at the expense of valerate and isovalerate.

Overall, feed-sorting behavior was less pronounced for the RED diet (Haselmann et al., 2019). Specifically, sorting for long particles was not affected by treatment. However, cows consuming CON sorted against medium and short particle fractions to a greater extent. Whereas RED cows sorted extensively for fine particles, cows consuming CON avoided this fraction. Due to further chopping, the RED diet contained higher proportions of hay and silage in the medium and short fractions; hence, the fine particle pool of the RED diet was enriched by hammer-milled hay. It is possible that these forages were more attractive to cows than the concentrate, because of the inclusion of less-palatable field beans in the latter. Kleefisch et al. (2018) reported that barn-dried hay of good quality is highly attractive to dairy cows. Therefore, it can be speculated that chopping contributed to achieve a better distribution of palatable components in the TMR, which may have resulted in less sorting of medium and short particles, leading to a better balance in dietary nutrient supply for the gut microbiota (Thomas and Russell, 2004). This could have contributed to the improved DMI and nutrient digestibility (Haselmann et al., 2019) and to the tendency toward lower fecal $\mathrm{pH}$, while maintaining the bacterial community structure and bacterial diversity observed in this study.

In the last few years, extensive research has described the gastrointestinal microbial communities in ruminants. However, given the limited information available for many gut bacterial taxa, we still do not know the potential underlying mechanisms for the association between a physical change of diet and shifts in gut bacterial taxa abundance, or the significant correlation between gut bacterial taxa and individual SCFA. For example, the family Christensenellaceae has also been associated with energy metabolism in nonruminants (Goodrich et al., 2014); therefore, further investigation of these taxa is needed. We also note that, although fermentation parameters can vary within an animal over a 24-h period as well as over several days, the use of a single sampling time, as we did in this study, provides a reference point for understanding the changes affecting the hindgut fermentation profile and bacterial population once the gastrointestinal tract has stabilized to a dietary regimen (Petri et al., 2019).

\section{CONCLUSIONS}

Overall, few but positive changes in the fecal microbiota occurred, highlighting the functional flexibility of fecal microorganisms and showing that reducing forage geometric mean particle size from 52 to $7 \mathrm{~mm}$ in rations of dairy cows fed forage-rich diets was effective for maintaining hindgut fermentation and bacterial diversity. Specifically, the tendency for reduction in fecal pH (0.08 units) can be considered minimal, and we found no evident risk of fecal dysbiosis with reduction of roughage particle size. Although relatively small, the 
tendency for enhancement of propionate concentration, with favorable changes of Lachnospiraceae, Ruminobacter, and Turicibacter, suggests increased availability of fermentable carbohydrates and improvement of hindgut ecology. This study should contribute to strengthening our knowledge of the utilization of highfiber ingredients in dairy rations to improve production performance and digestion, while preventing negative consequences on hindgut microbiota. In organically fed cows, this is particularly important, given that rations are usually formulated to include high-fiber bulky feed ingredients; reduction of particle size of forages may contribute to more efficient utilization of feedstuffs compared with feeds without particle size reduction. Future studies should consider further investigation on the effect of reducing diet particle size on hindgut fermentation and microbiota in cattle fed concentrate-rich diets.

\section{ACKNOWLEDGMENTS}

The authors thank the Austrian Federal Ministry for Sustainability and Tourism (Vienna), the Provincial Government of Salzburg, Raiffeisenverband Salzburg, and the "Ja! Natürlich!" brand of the REWE group (Wiener Neudorf, Austria) for funding provided. In addition, we are grateful to the Secondary School for Agriculture HBLA Ursprung (Elixhausen, Austria) for housing the experiment, to the farm staff of the Secondary School for Agriculture, especially Franz Griessner, for helping with the experimental work, and to Gruber Maschinen GmbH (Gaspoltshofen, Austria) and the Karl J. Mayer company (Krenglbach, Austria) for technical advice. We also thank Arife Sener (Institute of Animal Nutrition and Functional Plant Compounds, Department for Farm Animals and Veterinary Public Health, University of Veterinary Medicine, Vienna, Austria) for laboratory analysis regarding DNA extraction and purification. The authors have not stated any conflicts of interest.

\section{REFERENCES}

Allen, M. S. 1996. Physical constrains on voluntary intake of forages by ruminants. J. Anim. Sci. 74:3063-3075. https://doi.org/10 $.2527 / 1996.74123063 x$.

Allen, M. S. 2000. Effects of diet on short-term regulation of reed intake by lactating dairy cattle. J. Dairy Sci. 83:1598-1624. https:// doi.org/10.3168/jds.S0022-0302(00)75030-2.

Alstrup, L., K. Søegaard, and M. R. Weisbjerg. 2016. Effects of maturity and harvest season of grass-clover silage and of forage-toconcentrate ratio on milk production of dairy cows. J. Dairy Sci. 99:328-340. https://doi.org/10.3168/jds.2015-9802.

ASAE (American Society of Agricultural Engineers). 1992. ANSI/ ASAE S424.1 MAR1992 (R2017). Method of determining and expressing particle size of chopped forage materials by screening. American Society of Agricultural Engineers, St. Joseph, MI.
Bagheri Varzaneh, M., F. Klevenhusen, Q. Zebeli, and R. Petri. 2018. Scrophularia striata extract supports rumen fermentation and improves microbial diversity in vitro compared to monensin. Front. Microbiol. 9:2164. https://doi.org/10.3389/fmicb.2018.02164.

Callaway, T. R., S. E. Dowd, T. S. Edrington, R. C. Anderson, N. Krueger, N. Bauer, P. J. Kononoff, and D. J. Nisbet. 2010. Evaluation of bacterial diversity in the rumen and feces of cattle fed different levels of dried distillers grains plus solubles using bacterial tag-encoded FLX amplicon pyrosequencing. J. Anim. Sci. 88:3977-3983. https://doi.org/10.2527/jas.2010-2900.

Callaway, T. R., T. S. Edrington, R. C. Anderson, J. A. Byrd, and D. J. Nisbet. 2008. Gastrointestinal microbial ecology and the safety of our food supply as related to Salmonella. J. Anim. Sci. 86(Suppl. 14):E163-E172. https://doi.org/10.2527/jas.2007-0457.

Caporaso, J. G., J. Kuczynski, J. Stombaugh, K. Bittinger, F. D Bushman, E. K. Costello, N. Fierer, A. G. Peña, J. K. Goodrich, J. I. Gordon, G. A. Huttley, S. T. Kelley, D. Knights, J. E. Koenig, R. E. Ley, C. A. Lozupone, D. McDonald, B. D. Muegge, M. Pirrung, J. Reeder, J. R. Sevinsky, P. J. Turnbaugh, W. A. Walters, J. Widmann, T. Yatsunenko, J. Zaneveld, and R. Knight. 2010. QIIME allows analysis of high-throughput community sequencing data. Nat. Methods 7:335-336. https://doi.org/10.1038/nmeth.f .303 .

Castillo-Lopez, E., C. J. R. Jenkins, N. D. Aluthge, W. Tom, P. J. Kononoff, and S. C. Fernando. 2017. The effect of regular or reducedfat distillers grains with solubles on rumen methanogenesis and the rumen bacterial community. J. Appl. Microbiol. 123:1381-1395. https://doi.org/10.1111/jam.13583.

Castillo-Lopez, E., H. A. Ramirez Ramirez, T. J. Klopfenstein, C. L. Anderson, N. D. Aluthge, S. C. Fernando, T. Jenkins, and P. J. Kononoff. 2014. Effect of feeding dried distillers grains with solubles on ruminal biohydrogenation, intestinal fatty acid profile, and gut microbial diversity evaluated through DNA pyro-sequencing. J. Anim. Sci. 92:733-743. https://doi.org/10.2527/jas.2013-7223.

de Menezes, A. B., E. Lewis, M. O'Donovan, B. F. O'Neill, N. Clipson, and E. M. Doyle. 2011. Microbiome analysis of dairy cows fed pasture or total mixed ration diets. FEMS Microbiol. Ecol. 78:256-265. https://doi.org/10.1111/j.1574-6941.2011.01151.x.

Dewhurst, R. J., W. J. Fisher, J. K. S. Tweed, and R. J. Wilkins. 2003. Comparison of grass and legume silages for milk production. 1. Production responses with different levels of concentrate. J. Dairy Sci. 86:2598-2611. https://doi.org/10.3168/jds.S0022 $-0302(03) 73855-7$.

Dijkstra, J., J. L. Ellis, E. Kebreab, A. B. Strathe, S. López, J. France, and A. Bannink. 2012. Ruminal pH regulation and nutritional consequences of low pH. Anim. Feed Sci. Technol. 172:22-33. https:// doi.org/10.1016/j.anifeedsci.2011.12.005.

Dowd, S. E., T. R. Callaway, R. D. Wolcott, Y. Sun, T. McKeehan, R. G. Hagevoort, and T. S. Edrington. 2008. Evaluation of the bacterial diversity in the feces of cattle using $16 \mathrm{~S}$ rDNA bacterial tag-encoded FLX amplicon pyrosequencing (bTEFAP). BMC Microbiol. 8:125. https://doi.org/10.1186/1471-2180-8-125.

Dufreneix, F., P. Faverdin, and J.-L. Peyraud. 2019. Influence of particle size and density on mean retention time in the rumen of dairy cows. J. Dairy Sci. 102:3010-3022. https://doi.org/10.3168/ jds.2018-15926.

Dunkley, K. D., C. S. Dunkley, N. L. Njongmeta, T. R. Callaway, M. E. Hume, L. F. Kubena, D. J. Nisbet, and S. C. Ricke. 2007. Comparison of in vitro fermentation and molecular microbial profiles of high-fiber feed substrates incubated with chicken cecal inocula. Poult. Sci. 86:801-810. https://doi.org/10.1093/ps/86.5.801.

Durso, L. M., G. P. Harhay, T. P. L. Smith, J. L. Bono, T. Z. DeSantis, D. M. Harhay, G. L. Andersen, J. E. Keen, W. W. Laegreid, and M. L. Clawson. 2010. Animal-to-animal variation in fecal microbial diversity among beef cattle. Appl. Environ. Microbiol. 76:4858-4862. https://doi.org/10.1128/AEM.00207-10.

Edgar, R. C., B. J. Haas, J. C. Clemente, C. Quince, and R. Knight. 2011. UCHIME improves sensitivity and speed of chimera detection. Bioinformatics 27:2194-2200. https://doi.org/10.1093/ bioinformatics/btr381. 
European Commission. 2008. Commission Regulation (EC) No 889/2008 of 5 September 2008. Accessed Jun. 11, 2020. https:/ / eur-lex.europa.eu/LexUriServ/LexUriServ.do?uri=CONSLEG: 2008R0889:20100701:EN:PDF.

Fernando, S. C., H. T. Purvis II, F. Z. Najar, L. O. Sukharnikov, C. R. Krehbiel, T. G. Nagaraja, B. A. Roe, and U. Desilva. 2010. Rumen microbial population dynamics during adaptation to a high-grain diet. Appl. Environ. Microbiol. 76:7482-7490. https://doi.org/10 .1128/AEM.00388-10.

GfE. 2001. Recommendations for the Supply of Energy and Nutrients to Dairy Cows and Heifers. Gesellschaft für Ernährungsphysiologie (Society for Nutritional Physiology), DLG Verlag, Frankfurt am Main, Germany.

Goodrich, J. K., J. L. Waters, A. C. Poole, J. L. Sutter, O. Koren, R. Blekhman, M. Beaumont, W. Van Treuren, R. Knight, J. T. Bell, T. D. Spector, A. G. Clark, and R. E. Ley. 2014. Human genetics shape the gut microbiome. Cell 159:789-799. https://doi.org/10 $.1016 /$ j.cell.2014.09.053.

Gressley, T. F., M. B. Hall, and L. E. Armentano. 2011. Ruminant Nutrition Symposium: Productivity, digestion, and health responses to hindgut acidosis in ruminants. J. Anim. Sci. 89:1120-1130. https://doi.org/10.2527/jas.2010-3460.

Harmon, D. L., and C. J. Richards. 1997. Considerations for gastrointestinal cannulations in ruminants. J. Anim. Sci. 75:2248-2255. https://doi.org/10.2527/1997.7582248x.

Haselmann, A., K. Zehetgruber, B. Fuerst-Waltl, W. Zollitsch, W. Knaus, and Q. Zebeli. 2019. Feeding forages with reduced particle size in a total mixed ration improves feed intake, total tract digestibility, and performance of organic dairy cows. J. Dairy Sci. 102:8839-8849. https://doi.org/10.3168/jds.2018-16191.

Kammes, K. L., and M. S. Allen. 2012. Rates of particle size reduction and passage are faster for legume compared with cool-season grass, resulting in lower rumen fill and less effective fiber. J. Dairy Sci. 95:3288-3297. https://doi.org/10.3168/jds.2011-5022 Doi.org/ 10.3168/jds.2011-5022.

Khafipour, E., S. Li, H. M. Tun, H. Derakhshani, S. Moossavi, and J. C. Plaizier. 2016. Effects of grain feeding on microbiota in the digestive tract of cattle. Anim. Front. 6:13-19. https://doi.org/10 .2527/af.2016-0018.

Kleefisch, M. T., Q. Zebeli, E. Humer, L. Gruber, and F. Klevenhusen. 2018. Effects of feeding high-quality hay with graded amounts of concentrate on feed intake, performance and blood metabolites of cows in early lactation. Arch. Anim. Nutr. 72:290-307. https://doi .org/10.1080/1745039X.2018.1474004.

Kononoff, P. J., A. J. Heinrichs, and D. R. Buckmaster. 2003. Modification of the Penn State Forage and Total Mixed Ration Particle Separator and the effects of moisture content on its measurements. J. Dairy Sci. 86:1858-1863. https://doi.org/10.3168/jds.S0022 -0302(03) 73773-4.

Lladó, S., S. Covino, A. M. Solanas, M. Petruccioli, A. D'Annibale, and M. Vinas. 2015. Pyrosequencing reveals the effect of mobilizing agents and lignocellulosic substrate amendment on microbial community composition in a real industrial PAH-polluted soil. J. Hazard. Mater. 283:35-43. https://doi.org/10.1016/j.jhazmat 2014.08.065

Mao, S., R. D. Zhang, D. Wang, and W. Zhu. 2012. The diversity of the fecal bacterial community and its relationship with the concentration of volatile fatty acids in the feces during subacute rumen acidosis in dairy cows. BMC Vet. Res. 8:237. https://doi.org/10 $.1186 / 1746-6148-8-237$.

McAllister, T. A., H. D. Bae, G. A. Jones, and K. J. Cheng. 1994. Microbial attachment and feed digestion in the rumen. J. Anim. Sci. 72:3004-3018. https://doi.org/10.2527/1994.72113004x.

Mertens, D. R. 1997. Creating a system for meeting the fiber requirements of dairy cows. J. Dairy Sci. 80:1463-1481. https://doi.org/ 10.3168/jds.S0022-0302(97)76075-2.

Naadland, S. S., H. Steinshamn, S. J. Krizsan, and A. T. Randby, 2017. Effect of organic grass-clover silage on fiber digestion in dairy cows. Animal 11:1000-1007. https://doi.org/10.1017/ S1751731116002421.
Nasrollahi, S. M., M. Imani, and Q. Zebeli. 2015. A meta-analysis and meta-regression of the effect of forage particle size, level, source, and preservation method on feed intake, nutrient digestibility, and performance in dairy cows. J. Dairy Sci. 98:8926-8939. https://doi .org/10.3168/jds.2015-9681.

Oksanen, J., F. Guillaume Blanchet, R. Kindt, P. Legendre, P. R. Minchin, and R. B. O'Hara. 2015. Vegan: Community ecology package. R Package Version 2.3-0. Accessed Sep. 15, 2019. http:// CRAN.R-project.org/package=vegan.

Petri, R. M., M. Münnich, Q. Zebeli, and F. Klevenhusen. 2019. Graded replacement of corn grain with molassed sugar beet pulp modulates the fecal microbial community and hindgut fermentation profile in lactating dairy cows. J. Dairy Sci. 102:5019-5030. https://doi.org/10.3168/jds.2018-15704.

Plaizier, J. C., M. Danesh Mesgaran, H. Derakhshani, H. Golder, E. Khafipour, J. L. Kleen, I. Lean, J. Loor, G. Penner, and Q. Zebeli. 2018. Review: Enhancing gastrointestinal health in dairy cows. Animal 12(Suppl. 2):s399-s418. https://doi.org/10.1017/ S1751731118001921.

Plaizier, J. C., S. Li, H. M. Tun, and E. Khafipour. 2017. Nutritional models of experimentally-induced subacute ruminal acidosis (SARA) differ in their impact on rumen and hindgut bacterial communities in dairy cows. Front. Microbiol. 7:2128. https://doi .org/10.3389/fmicb.2016.02128.

Probst, M., M. Gómez-Brandón, T. Bardelli, M. Egli, H. Insam, and J. Ascher-Jenull. 2018. Bacterial communities of decaying Norway spruce follow distinct slope exposure and time-dependent trajectories. Environ. Microbiol. 20:3657-3670. https://doi.org/10.1111/ 1462-2920.14359.

Qumar, M., R. Khiaosa-Ard, P. Pourazad, S. U. Wetzels, F. Klevenhusen, W. Kandler, J. R. Aschenbach, and Q. Zebeli. 2016. Evidence of in vivo absorption of lactate and modulation of short chain fatty acid absorption from the reticulorumen of non-lactating cattle fed high concentrate diets. PLoS One 11:e0164192. https://doi.org/10 .1371/journal.pone.0164192.

Ribeiro, G. O., D. B. Oss, Z. He, J. R. Gruninger, C. Elekwachi, R. J. Forster, W. Yang, K. A. Beauchemin, and T. A. McAllister. 2017. Repeated inoculation of cattle rumen with bison rumen contents alters the rumen microbiome and improves nitrogen digestibility in cattle. Sci. Rep. 7:1276. https://doi.org/10.1038/s41598-017-01269 $-3$.

Russell, J. B. 2002. Rumen Microbiology and Its Role in Ruminant Nutrition. Cornell University, Ithaca, NY.

Russell, J. B., and D. B. Wilson. 1996. Why are ruminal cellulolytic bacteria unable to digest cellulose at low pH? J. Dairy Sci. 79:1503-1509. https://doi.org/10.3168/jds.S0022-0302(96)76510 -4 .

San-Juan-Vergara, H., E. Zurek, N. J. Ajami, C. Mogollon, M. Peña, I. Portnoy, J. I. Vélez, C. Cadena-Cruz, Y. Diaz-Olmos, L. Hurtado-Gómez, S. Sanchez-Sit, D. Hernández, I. Urruchurtu, P. DiRuggiero, E. Guardo-García, N. Torres, O. Vidal-Orjuela, D. Viasus, J. F. Petrosino, and G. Cervantes-Acosta. 2018. A Lachnospiraceae-dominated bacterial signature in the fecal microbiota of HIV-infected individuals from Colombia, South America. Sci. Rep. 8:4479. https://doi.org/10.1038/s41598-018-22629-7.

Schären, M., C. Drong, K. Kiri, S. Riede, M. Gardener, U. Meyer, J. Hummel, T. Urich, G. Breves, and S. Dänicke. 2017. Differential effects of monensin and a blend of essential oils on rumen microbiota composition of transition dairy cows. J. Dairy Sci. 100:27652783. https://doi.org/10.3168/jds.2016-11994.

Schulze, A. K., P. Nørgaard, M. V. Byskov, and M. R. Weisbjerg. 2015. Evaluation of physical structure value in spring-harvested grass/ clover silage and hay fed to heifers. Animal 9:275-284. https://doi .org/10.1017/S1751731114002286.

Shanks, O. C., C. A. Kelty, S. Archibeque, M. Jenkins, R. J. Newton, S. L. McLellan, S. M. Huse, and M. L. Sogin. 2011. Community structures of fecal bacteria in cattle from different animal feeding operations. Appl. Environ. Microbiol. 77:2992-3001. https://doi .org/10.1128/AEM.02988-10. 
Sutton, J. D. 1985. Digestion and absorption of energy substrates in the lactating cow. J. Dairy Sci. 68:3376-3393. https://doi.org/10 $.3168 /$ jds.S0022-0302(85)81251-0.

Tafaj, M., H. Steingass, and W. Drochner. 2001. Influence of hay particle size at different concentrate and feeding levels on digestive processes and feed intake in ruminants. 2. Passage, digestibility and feed intake. Arch. Tierernahr. 54:243-259. https://doi.org/10 $.1080 / 17450390109381981$.

Tafaj, M., Q. Zebeli, C. Baes, H. Steingass, and W. Drochner. 2007. A meta-analysis examining effects of particle size of total mixed rations on intake, rumen digestion and milk production in highyielding dairy cows in early lactation. Anim. Feed Sci. Technol. 138:137-161. https://doi.org/10.1016/j.anifeedsci.2007.06.020.

Tao, S., P. Tian, Y. Luo, J. Tian, C. Hua, Y. Geng, R. Cong, Y. Ni, and R. Zhao. 2017. Microbiome-metabolome responses to a highgrain diet associated with the hind-gut health of goats. Front. Microbiol. 8:1764. https://doi.org/10.3389/fmicb.2017.01764.

Tayyab, U., R. G. Wilkinson, C. K. Reynolds, and L. A. Sinclair. 2018. Particle size distribution of forages and mixed rations, and their relationship with ration variability and performance of UK dairy herds. Livest. Sci. 217:108-115. https://doi.org/10.1016/j.livsci 2018.09.018

Thomas, S., and J. B. Russell. 2004. The effect of cellobiose, glucose, and cellulose on the survival of Fibrobacter succinogenes A3C cultures grown under ammonia limitation. Curr. Microbiol. 48:219223. https://doi.org/10.1007/s00284-003-4151-0.

Van Soest, P. J. 1994. Nutritional Ecology of the Ruminant. Comstock Pub., Ithaca, NY.

Velasco-Galilea, M., M. Piles, M. Viñas, O. Rafel, O. González-Rodríguez, M. Guivernau, and J. P. Sánchez. 2018. Rabbit microbiota changes throughout the intestinal tract. Front. Microbiol. 9:2144. https://doi.org/10.3389/fmicb.2018.02144.

Wallace, R. J., J. A. Rooke, N. McKain, C. A. Duthie, J. J. Hyslop, A. Ross, A. Waterhouse, M. Watson, and R. Roehe. 2015. The rumen microbial metagenome associated with high methane production in cattle. BMC Genomics 16:839. https://doi.org/10.1186/s12864 $-015-2032-0$

Warnes, G. R., B. Bolker, L. Bonebakker, R. Gentleman, W. H. Andy Liaw, and T. Lumley. 2015. Gplots: Various R programming tools for plotting data. R Package Version 2.17.0. Accessed Sep. 15, 2019. http://CRAN.Rproject.org/package $=$ gplots.

Wilkinson, J. M. 2011. Re-defining efficiency of feed use by livestock. Animal 5:1014-1022. https://doi.org/10.1017/S175173111100005X.

Zabielski, R., V. Lesniewska, and P. Guilloteau. 1997. Collection of pancreatic juice in experimental animals: Mini-review of materials and methods. Reprod. Nutr. Dev. 37:385-399.

Zebeli, Q., M. Tafaj, I. Weber, J. Dijkstra, H. Steingass, and W. Drochner. 2007. Effects of varying dietary forage particle size in two concentrate levels on chewing activity, ruminal mat characteristics, and passage in dairy cows. J. Dairy Sci. 90:1929-1942. https://doi .org/10.3168/jds.2006-354.

Zhao, X. H., S. Zhou, L. B. Bao, X. Z. Song, K. H. Ouyang, L. J. Xu, K. Pan, C. J. Liu, and M. R. Qu. 2018. Response of rumen bacterial diversity and fermentation parameters in beef cattle to diets containing supplemental daidzein. Ital. J. Anim. Sci. 17:643-649. https://doi.org/10.1080/1828051X.2017.1404943.

\section{ORCIDS}

Ezequias Castillo-Lopez @ https://orcid.org/0000-0002-9304-2351

Andreas Haselmann (ㄴ) https://orcid.org/0000-0002-2575-5296

Renee M. Petri ๑ https://orcid.org/0000-0002-8209-8261

Wilhelm Knaus ํ https://orcid.org/0000-0001-9909-5422

Qendrim Zebeli @ https://orcid.org/0000-0001-5188-9004 